\section{Somatotype, Body Composition and Explosive Power of Athlete and Non- Athlete}

\author{
Sukanta Saha* \\ Assistant Professor, Department of Physical Education, Memari College, Memari, Burdwan, West Bengal, India
}

*Corresponding author: Sukanta Saha, Assistant Professor, Department of Physical Education, Memari College, Memari, Burdwan, West Bengal, India, Tel: 919434249959; Email: sahasukanta1980@gmail.com

Copyright: $\odot 2014$ Saha S, et al. This is an open-access article distributed under the terms of the Creative Commons Attribution License, which permits unrestricted use, distribution, and reproduction in any medium, provided the original author and source are credited.

Received date: March 18, 2014; Accepted date: April 22, 2014; Published date: April 30, 2014

\begin{abstract}
The aim of this study was to identify the effect of somatotype and body composition variables on leg explosive power of college level men students. The sample consisted of 500 young college students, divided into two groups: athletes $(\mathrm{N}=250)$ undergoing Bachelor of Physical Education course whose mean age $23.86 \pm 0.36$ years; and nonathletes $(\mathrm{N}=250)$ college students who do not take part regular physical activities and mean age $22.16 \pm 0.88$ years. The somatotype was assessed using the Heath \& Carter method. Assessing body composition of the subject various anthropometric measurements were taken. Sargent vertical jump test was used to measure leg explosive power. The measures were compared between the two groups using the Student $t$-test for independent samples. The two groups differed significantly $(p \leq 0.01$ ) in terms of body weight, \% body fat, lean body mass, \% skeletal muscle mass and somatotype. The findings of the present study showing that athlete have higher mean values in leg explosive power $(p \leq 0.01)$ than non-athlete. The leg explosive power was positively significantly $(p \leq 0.01)$ correlated with $\%$ skeletal muscle mass, lean body mass, mesomorphy and ectomorphy components of somatotype; on the other hand body weight, height, \% body fat, body surface area and endomorphy component of somatotype significantly ( $p \leq$ 0.01) negatively correlated. In conclusion, somatotype and body composition variables are important factors in determining leg explosive power.
\end{abstract}

\section{Key words:}

Vertical jump; \% body fat; Lean bodymass

\section{Introduction}

Somatotyping has a relatively long tradition in human biology. Since the early development of Sheldon's somatotyping system, researchers have studied the relation of somatotype and body composition to physical performance [1]. About $25 \%$ to $65 \%$ of the variance in physical fitness tests could be explained by somatotype in adult sportsmen $[2,3]$. Power is the product of force applied on the athlete and the velocity of the athlete $[4,5]$. The best way to test the explosive power is to find how much of C.G can be raised in standing jump. This can be determined by measuring the difference between a people's jumping reach and his standing reach, with his arm fully extended upward.

Vertical jump is commonly used as an index for the power of the lower limb or explosive leg power [6-9]. Vertical jumping ability is an important fundamental skill for many athletic activities. Vertical jump height is a measurement that coaches, health care professionals, and strength and conditioning professionals frequently use [10] as an objective functional measurement. Many coaches consider vertical jump as an essential skill contributing to higher performance in numerous sports, including football, basketball, diving, and volleyball $[11,12]$.

Some authors consider vertical jump performance a measurement of muscular power of the lower extremity [13-15], whereas others see the vertical jump as a measurable coordinated activity [16-20]. Vertical jump is a frequently assessed athletic skill used to measure improvement of an athlete's capabilities throughout a specific training program [21].

The performance of the athlete in the vertical jump is closely related to biomechanics. Velocity, force, acceleration and momentum are the biomechanical principles involved in any type of vertical jump [22,23]. Apart from the biomechanical and physiological factors, anthropometric and body composition characteristics also play significant roles in vertical jump performance.

Studies on anthropometric and body composition characteristics have been carried out by a number of researchers [5,16,21,24-28]. However, only a few studies on the performance of college level students in leg explosive power have ever been published. Therefore, the objective of this article was to determine the influence of somatotype and body composition characteristics on leg explosive power. The other aim was to compare leg explosive power in young athlete and non-athlete of college level men students.

\section{Material and Methods}

The present study was conducted on 250 athletes and 250 nonathletes (total 500) young college levels male students (age range 18-25 years). Athletes were completed one year Bachelor of Physical Education (B.P.Ed) course and took part in obligatory physical activities under their course of study and non-athlete students were not participated regular physical activity. The subjects were selected from nineteen colleges located in nine different districts of WestBengal in India irrespective of their caste, religion, dietary habits and socio-economic status. The age of the subjects were calculated from the date of birth as recorded in their institution. The investigation 
Page 2 of 4

received ethical approval from the Visva Bharati University Research Degrees Ethics Committee.

The anthropometric measurements were carried out using standard instruments and in accordance with the methodology recommended by the International Society for the Advancement of Kinanthropometry. All the anthropometrics measurements of the subjects were taken right side of the body as per the direction of the Leon and The Koerner Foundation Study Group in 1973. Researcher was used the technical error of measurement (TEM) for evaluating the consistency, or precision, of the measure on a given variable. The TEM is the square root of the sum of the differences between measures one and two squared, divided by twice the number of subjects. The TEM provides an estimate of the measurement error that is in the units of measurement of the variable. The TEM was lower than $2 \%$ for skin folds and $0.5 \%$ for the other measurements.

The response variable was leg explosive power; the explanatory variables were height, weight, corrected thigh girth (thigh skin fold subtract from thigh girth), corrected calf girth (arm skinfold subtract from arm girth), \% body fat, lean body mass, \% skeletal muscle mass, $\%$ skeletal mass, body surface area and somatotype components (endomorphy, mesomorphy, ectomorphy). The height was measured to the nearest $0.1 \mathrm{~cm}$ using a stadiometer. The subjects wore light clothing and were weighted to the nearest $0.1 \mathrm{~kg}$ using a calibrated digital scale. Researcher also examine five muscle girths (upper arm, fore arm, chest, thigh and calf) in $\mathrm{cm}$, four bone diameters (humerus, bistyloid, femur and bimalleolus) in $\mathrm{cm}$, and eight skin folds thickness (triceps, sub-scapular, suprailiac, pectoral, axilla, abdominal, thigh and calf) in mm. For calculating body density of the subjects Jackson and Pollock [29] equation was adopted. The Siri equation [30] was used to convert body density to percent body fat of each participant.

Poortman's [31] and Drinkwater et al. [32] formula was taken up for assessing skeletal muscle mass and skeletal mass respectively. Measurement of body surface area (BSA) of the subjects Mosteller's formula [33] was used. Somatotype components (endomorphy, mesomorphy and ectomorphy) of the subjects were calculated according to Carter and Heath anthropometric method [34]. Lastly, for explosive power Sargent vertical jump test was conducted. First, confidence of appropriate physical condition were achieved, correct process of measurement were described for them and then subjects warmed up completely to perform the test. Subject stands side on to a wall and reaches up with the hand closest to the wall. Keeping the feet flat on the ground, the point of the fingertips was recorded. This is called the standing reach height. The subject then stands away from the wall, and jumps vertically as high as possible using both arms and legs to assist in projecting the body upwards. Attempt to touch the wall at the highest point of the jump. The difference in distance between the standing reach height and the jump height was the score. The best of three attempts was recorded in $\mathrm{cm}$. There was a one minute resting period between each jump in order to overcome fatigue.

\section{Statistical Analysis}

Descriptive statistics (mean, \pm standard deviation) and Student $\mathrm{t}$ test for independent samples were used for compared between the athletes and non-athletes. Pearson's correlation of coefficients was used to establish the correlations of vertical jump with other variables in athletes and non-athletes of college level students. Data were analyzed using SPSS (Statistical Package for Social Science) version 17.0. A $1 \%$ level of probability was used to indicate statistical significance.

\section{Results}

Table 1 depicts the mean and standard deviation of the variables of athlete and non-athlete. The mean height of the college aged athlete and non-athlete is parallel, which are $168.82 \pm 5.63 \mathrm{~cm}$ and $168.33 \pm$ $5.59 \mathrm{~cm}$ respectively. Although athletes have higher mean body weight $(60.44 \pm 5.53 \mathrm{~kg})$ than non-athletes do $(58.43 \pm 6.48 \mathrm{~kg})$, but they have lower mean \% body fat $(12.37 \pm 3.01 \%)$ than non-athletes $(14.36 \pm$ $3.69 \%)$. Athletes have higher mean corrected thigh girth (49.32 \pm 2.97 $\mathrm{cm})$ and mean corrected calf girth $(32.52 \pm 1.84 \mathrm{~cm})$, as well as greater mean \% skeletal muscle mass $(49.79 \pm 3.22 \%)$, \% skeletal mass $(13.57$ $\pm 1.34 \%)$, lean body mass $(52.90 \pm 4.55 \mathrm{~kg})$, body surface area $(1.68 \pm$ $0.09 \mathrm{~m} 2)$, mesomorphy component $(4.67 \pm 0.88)$ and mean vertical jumping ability $(49.13 \pm 6.87 \mathrm{~cm})$. In contrast, the mean value for corrected thigh girth, corrected calf girth, $\%$ skeletal muscle mass, $\%$ skeletal mass, lean body mass, body surface area, mesomorphy component, and mean vertical jumping ability of non-athletes are $47.22 \pm 3.91 \mathrm{~cm}, 30.02 \pm 2.31 \mathrm{~cm}, 40.35 \pm 3.32 \%, 13.38 \pm 0.98 \%, 49.95$ $\pm 5.23 \mathrm{~kg}, 1.65 \pm 0.10 \mathrm{~m} 2,3.44 \pm 1.23$ and $42.41 \pm 6.43 \mathrm{~cm}$ respectively.

\begin{tabular}{|c|c|c|c|c|c|c|}
\hline \multicolumn{2}{|l|}{ Variables } & \multicolumn{2}{|l|}{ Athlete } & \multicolumn{2}{|c|}{ Non-Athlete } & \multirow{3}{*}{$\frac{\text { t-Value }}{}$} \\
\hline & & Mean & S.D. & Mean & S.D. & \\
\hline \multirow[t]{4}{*}{$\begin{array}{l}\text { Anthropometric } \\
\text { Measurements }\end{array}$} & Height $(\mathrm{cm})$ & 168.82 & 5.63 & $\begin{array}{l}168.3 \\
3\end{array}$ & 5.59 & \\
\hline & Weight (kg) & 60.44 & 5.53 & 58.43 & 6.48 & $3.71^{* *}$ \\
\hline & $\begin{array}{l}\text { Corrected Thigh } \\
\text { Girth }(\mathrm{cm})\end{array}$ & 49.32 & 2.97 & 47.22 & 3.91 & $9.54^{\star *}$ \\
\hline & $\begin{array}{l}\text { Corrected Calf } \\
\text { Girth }(\mathrm{cm})\end{array}$ & 32.52 & 1.84 & 30.02 & 2.31 & $18.89^{* *}$ \\
\hline \multirow{5}{*}{$\begin{array}{l}\text { Body } \\
\text { Composition }\end{array}$} & $\%$ Body Fat & 12.37 & 3.01 & 14.36 & 3.69 & $6.58^{\star *}$ \\
\hline & $\begin{array}{ll}\% & \text { Skeletal } \\
\text { Mass } & \end{array}$ & 13.57 & 1.34 & 13.38 & 0.98 & 1.80 \\
\hline & $\begin{array}{ll}\% & \text { Skeletal } \\
\text { Muscle } & \text { Mass }\end{array}$ & 49.79 & 3.22 & 40.35 & 3.32 & $4.90^{* *}$ \\
\hline & $\begin{array}{ll}\text { Lean } & \text { Body } \\
\text { Mass } & \end{array}$ & 52.90 & 4.55 & 49.95 & 5.23 & $6.70^{\star *}$ \\
\hline & $\begin{array}{l}\text { Body Surface } \\
\text { Area }\left(\mathrm{m}^{2}\right)\end{array}$ & 1.68 & 0.09 & 1.65 & 0.10 & $3.51^{* \star}$ \\
\hline \multirow[t]{3}{*}{ Somatotype } & Endomorphy & 2.86 & 0.86 & 4.87 & 1.01 & $6.17^{\star \star}$ \\
\hline & Mesomorphy & 4.67 & 0.88 & 3.44 & 1.23 & $5.51^{\star *}$ \\
\hline & Ectomorphy & 3.85 & 0.74 & 3.34 & 1.18 & $5.42^{\star *}$ \\
\hline $\begin{array}{l}\text { Explosive } \\
\text { Power }\end{array}$ & $\begin{array}{l}\text { Vertical Jump } \\
(\mathrm{cm})\end{array}$ & 49.13 & 6.87 & 42.41 & 6.43 & $11.24^{* *}$ \\
\hline
\end{tabular}

Table 1. Descriptive statistics and t-value of body composition, somatotype and leg explosive power of athlete and non-athlete

Pearson coefficient of correlation of body composition variables and somatotype components with leg explosive power was presented in Table 2. All the variables were statistically either positively or negatively significant correlation at 0.01 level with leg explosive power irrespective of athlete or non-athlete. 
Page 3 of 4

\begin{tabular}{|c|c|c|}
\hline Variables & Athlete & Non-Athlete \\
\hline Height $(\mathrm{cm})$ & $-0.432^{* *}$ & $-0.291^{* *}$ \\
\hline Weight (Kg) & $-0.279^{* *}$ & $-0.175^{\star *}$ \\
\hline Corrected Thigh Girth $(\mathrm{cm})$ & $0.531^{\star *}$ & $0.598^{\star *}$ \\
\hline Corrected Calf Girth (cm) & $0.419^{* *}$ & $0.244^{* *}$ \\
\hline$\%$ Body Fat & $-0.454^{\star *}$ & $-0.531^{* *}$ \\
\hline$\%$ Skeletal Muscle Mass & $0.285^{\star *}$ & $0.312^{* *}$ \\
\hline$\%$ Skeletal Mass & $0.351^{* *}$ & $0.363^{* *}$ \\
\hline Lean Body Mass (kg) & $0.527^{\star *}$ & $0.412^{* \star}$ \\
\hline Body Surface Area (m2) & $-0.339^{* *}$ & $-0.226^{* *}$ \\
\hline Endomorphy & $-0.448^{\star *}$ & $-0.508^{* *}$ \\
\hline Mesomorphy & $0.518^{* \star}$ & $0.426^{* *}$ \\
\hline Ectomorphy & $0.329^{* \star}$ & $0.248^{* *}$ \\
\hline \multicolumn{3}{|l|}{$\left(^{* \star}\right)$ indicates $p<0.01$} \\
\hline
\end{tabular}

monitored so that the body fat will be flushed away without losing the nutrition.

In present study the mean somatotype of the college level athletes is ectomorphic mesomorph (2.86-4.67-3.85) on the other hand mean somatotype of non-athlete students is balanced endomorph (4.87-3.44-3.34). A higher mesomorphic rating in athletes than the non-athlete college level students suggests that the former are more muscular than the later (Table 1). High mesomorphic ratings in athletes can be attributed to take part in obligatory physical activities under their course of study, as there is positive association between mesomorphic component and physical activity [36,37]. Mesomorphy and ectomorphy components of somatotype are significantly ( $\mathrm{p} \leq$ 0.01) positive correlated with leg explosive power [38], whereas endomorphy component found significantly $(p \leq 0.01)$ negative correlation with leg explosive power irrespective of athlete and nonathlete.

\section{Conclusions}

The leg explosive power for Indian college level male athletes is significantly higher than that of their non-athlete counterparts. Body weight, corrected thigh girth, corrected calf girth, \% skeletal muscle mass, lean body mass and mesomorphy component of somatotype is significantly positive association to the leg explosive power of Indian college level male athletes and non-athletes. In contrast, endomorphy component of somatotype and \% body fat is an important body composition factor that has a significant negative relationship with leg explosive power of both athlete and non-athlete. Reducing the amount of body fat with proper physical training and dietary planning will be helpful to improve the leg explosive power. As the present study is examine relationships between leg explosive power with somatotype and various body composition variables in men athlete and nonathlete college aged students of few districts in India, so more research on larger area and other sex is needed to confirm or refute this finding.

\section{References}

1. Raudsepp L, Jurimae T (1996) Somatotype and physical fitness of prepubertal children. Collegium Antropologicum 20: 53-59.

2. Laubach L, McConville J (1969) The relationship of strength to body size and typology. Medicine and Science in Sports 1: 189-194.

3. Malina RM (1975) Anthropometric correlates of strength and motor performance. Exerc Sport Sci Rev 3: 249-274.

4. Reiser RF, Rocheford EC, Armstrong CJ (2006) Building a better understanding of basic mechanical principles through analysis of the vertical jump. Strength Cond J 28: 70-80.

5. Roschel H, Batista M, Monteiro R, Bertuzzi RC, Barroso R, et al. (2009) Association between neuromuscular tests and kumite performance on the brazilian karate national team. J Sports Sci Med 8: 20-24.

6. Chu DA (1996) Explosive power \& strength. Human Kinetics, Champaign, IL.

7. Moir G, Button C, Glaister M, Stone MH (2004) Influence of familiarization on the reliability of vertical jump and acceleration sprinting performance in physically active men. J Strength Cond Res 18: 276-280.

8. Richards DK (1968) A two-factor theory of the warm-up effect in jumping performance. Res Q 39: 668-673.

9. Shellock FG, Prentice WE (1985) Warming-up and stretching for improved physical performance and prevention of sports-related injuries. Sports Med 2: 267-278.

10. Waggener GT, Barfield WR, Sessoms ED (2002) Prediction of maximal vertical jump height, revisited. Int Sports J 6: 107. 
11. Baker D (1996) Improving vertical jump performance through general, special, and speci?c strength training: A brief review. J Strength Cond Res 10: 131-136.

12. Klavora P (2000) Vertical jump test: A critical review. Strength Cond J 22: 70-74.

13. Liebermann DG, Katz L (2003) On the assessment of lower limb muscular power capability. Isokinetics Exerc Sci 11: 87-94.

14. Patterson DD, Peterson DF (2004) Vertical jump and leg power norms for young adults. Meas Phys Educ Exer Sci 8: 33-41.

15. Tricoli V, Lamas L, Carnevale R, Ugrinowitsch C (2005) Short-term effects on lower-body functional power development: weightlifting vs. vertical jump training programs. J Strength Cond Res 19: 433-437.

16. Noorul HR, Pieter W, Erie ZZ (2008) Physical fitness of recreational adolescent taekwondo athletes. Braz J Biomotricity 2: 230-240.

17. Myer GD, Ford KR, Palumbo JP, Hewett TE (2005) Neuromuscular training improves performance and lower-extremity biomechanics in female athletes. J Strength Cond Res 19: 51-60.

18. Tomioka M, Owings TM, Grabiner MD (2001) Lower extremity strength and coordination are independent contributors to maximum vertical jump height. J Appl Biomech 17:181-187.

19. Eloranta V (2003) Influence of sports background on leg muscle coordination in vertical jumps. ElectromyogrClinNeurophysiol 43: 141-156.

20. Greenberger HB, Paterno MV (1995) Relationship of knee extensor strength and hopping test performance in the assessment of lower extremity function. J Orthop Sports Phys Ther 22: 202-206.

21. Markovic G, Jaric S (2007) Is vertical jump height a body sizeindependent measure of muscle power? J Sports Sci 25: 1355-1363.

22. Bobbert MF, Van Soest AJ (1994) Effects of muscle strengthening on vertical jump height: a simulation study. Med Sci Sports Exerc 26: 1012-1020.

23. Kroon S (2000) Vertical jump ability of elite volleyball players compared to elite athletes in other team sports.

24. Dizon JMR (2012) Grimmer-Somers K. Making Filipino Taekwondo athletes internationally competitive: an international comparison of anthropometric and physiologic characteristics. J Sport Medic Doping Studies 2: 105-111.
25. Aslan CS, Koc H, Aslan M, Ozer U (2011) The Effect of Height on the Anaerobic Power of Sub-Elite Athletes. World Applied Science Journal 12: 208-211.

26. Davis DS, Briscoe DA, Markowski CT, Saville SE, Taylor CJ (2003) Physical characteristics that predict vertical jump performance in recreational male athletes. Phys Ther Sport 4: 167-174.

27. Wyon M, Allen N, Angioi M, Nevill A, Twitchett E (2006) Anthropometric factors affecting vertical jump height in ballet dancers. J Dance Med Sci 10: 106-110.

28. Reeves RA, Hicks OD, Navalta JW (2008) The relationship between upper arm anthropometrical measures and vertical jump displacement. Int J Exerc Sci 1: 22-29.

29. Jackson AS, Pollock ML (1978) Generalized equations for predicting body density of men. Br J Nutr 40: 497-504.

30. Siri WE (1956) Gross composition of the body. in: advances in biological and medical physics (Vol. IV) Academic Press, New York.

31. Poortmans JR, Boisseau N, Moraine JJ, Moreno-Reyes R, Goldman S (2005) Estimation of total-body skeletal muscle mass in children and adolescents. Med Sci Sports Exerc 37: 316-322.

32. Drinkwater BL, Nilson K, Chesnut CH 3rd, Bremner WJ, Shainholtz S, et al. (1984) Bone mineral content of amenorrheic and eumenorrheic athletes. N Engl J Med 311: 277-281.

33. Mosteller RD (1987) Simplified calculation of body-surface area. N Engl J Med 317: 1098.

34. Carter L, Heath BH (1990) Somatotyping. Development and applications. Cambridge: University Press, New York.

35. Ostojic SM, Mazic S, Dikic N (2006) Profiling in basketball: physical and physiological characteristics of elite players. J Strength Cond Res 20: 740-744.

36. Malina RM, Geithner CA (2011) Body composition of young athletes. Am J Lifestyle Med 5: 262-278.

37. Ozener B, Duyar I (2008) The effect of labour on somatotype of males during the adolescent growth period. Homo 59: 161-172.

38. Lewandowska J, Bů̊,ko K, Pastuszak A, Boguszewska K (2011) Somatotype variables related to muscle torque and power in judoists. J Hum Kinet 30: 21-28. 